\title{
Corporate campaign contributions and abnormal stock returns after presidential elections
}

Jürgen Huber, Michael Kirchler

Working Papers in Economics and Statistics

2008-18 


\section{University of Innsbruck \\ Working Papers in Economics and Statistics}

The series is jointly edited and published by

- Department of Economics

- Department of Public Finance

- Department of Statistics

Contact Address:

University of Innsbruck

Department of Public Finance

Universitaetsstrasse 15

A-6020 Innsbruck

Austria

Tel: $\quad$ + 435125077171

Fax: $\quad+435125072970$

E-mail: eeecon@uibk.ac.at

The most recent version of all working papers can be downloaded at http://eeecon.uibk.ac.at/wopec/

For a list of recent papers see the backpages of this paper. 


\title{
Corporate campaign contributions and abnormal stock
}

\author{
returns after presidential elections
}

\author{
Juergen Huber*and Michael Kirchler ${ }^{\dagger}$
}

JEL D72, G10, P16

\begin{abstract}
Contributions by investor-owned companies play major roles in financing the campaigns of candidates for elective office in the United States. We look at the presidential level and analyze contributions by companies before an election and their stock market performance following US presidential elections from 1992 to 2004. We find that companies experienced abnormal positive post-election returns with (i) a higher percentage of contributions given to the eventual winner and (ii) with a higher total contribution given. Hypothetical portfolios of the 30 largest corporate contributors formed according to (i) the percentage of contributions given to the winner in a presidential election and (ii) the total contribution (divided by market capitalization) would have earned significant abnormal returns in the two years after an election. While all results hold

\footnotetext{
${ }^{*}$ Corresponding author. Innsbruck University School of Management, Department of Banking and Finance, Universitaetsstrasse 15, 6020 Innsbruck, Austria. e-mail: juergen.huber@uibk.ac.at.

${ }^{\dagger}$ Innsbruck University School of Management, Department of Banking and Finance, Universitaetsstrasse 15, 6020 Innsbruck, Austria and Department of Economics, Centre for Finance, University of Gothenburg, P.O. Box 600, 40530 Gothenburg, Sweden. e-mail: michael.kirchler@uibk.ac.at
} 
for Bill Clinton and George W. Bush, they are stronger by a magnitude of two to three under W. Bush.

Keywords: Presidential Election, Corporate Campaign Contributions, Abnormal Returns

\section{Introduction}

Politics and business are intertwined in many ways - via campaign contributions, lobbying, public funding of projects, public procurement, and many other factors, politicians and business owners exert considerable influence on one another. In this paper we focus on campaign contributions by corporations before a presidential election and the stock market performance of contributing corporations afterwards. Differing from most earlier studies, we look at presidential elections as, by setting the national agenda, proposing an annual budget, and defining public policies and myriad other programs, conferring on the President of the United States and his administration affect the economy in many ways; presidential elections are natural "targets" for rent-seeking activities (Tullock 1967; Krueger 1974; Lott 2000). From a rent-seeking perspective companies can have an incentive to spend money for presidential candidates and as presidential hopefuls need to raise large sums, campaign contributions by companies and business associations are usually a welcome source of funds (Ansolabehere et al. 2003). After the 2010 Supreme Court ruling in Citizens United against FEC (case 08-205, 558 U.S. 50 (2010)), which grants companies the same free speech rights (and thus spending in the political process) as those accorded to individuals, corporate campaign contributions are likely to become even more important in the future. 
In the first of two research questions we analyze the effects of campaign contributions from the company's perspective. Specifically, we explore whether the total contributions of a company and the distribution of contributions to the winner and loser of an election were correlated with abnormal returns to its stocks. Both variables are examined using data from the presidential elections over the four cycles 1992-2004. We find that (i) the log of total contributions given to the winner in a presidential election and (ii) the log of a company's total contribution (divided by market capitalization) were both positively and significantly related to its stock market performance in the two years after an election. While both effects were visible under Clinton, the amplitude was two to three times larger under Bush.

In our second research question we analyze whether an investor could have earned economically and statistically significant abnormal returns if he had picked stocks according to contribution data. We find that hypothetical portfolios of the 30 largest contributors according to (i) the percentage of contributions given to the winner in a presidential election and (ii) total contribution (divided by market capitalization) would have yielded significant abnormal returns. An investor selecting a portfolio according to (i) would have earned significant abnormal returns of up to $6.6 \%$ per year when the CAPM is applied during the first year after an election. Investing in a portfolio formed according to (ii) would have yielded abnormal annual returns of up to $15.5 \%$ for the same observation period.

We want to stress that our results should not be seen as a moral judgment. We cannot distinguish whether the stock prices of firms supporting the winner of an election rise because firms contribute to politicians whose intrinsic views match the firms' interest or whether donations affect a president's policies. A government need not be corrupt for companies supporting it to perform well; e.g., the known Republican attitudes towards tort law, 
environmental protection, and national defense are quite different from the Democrats' attitude to these issues and thus the outcome of a presidential election may influence many companies' profits without the government explicitly fulfilling any demands of big contributors. It is likely that, before the election, companies make contributions to the candidate they expect to implement policies that favor them.

The paper is organized as follows: Section 2 briefly reviews relevant literature, Section 3 provides a description of the data set. The econometric model is presented in Section 4 and the results follow in Section 5. Section 6 discusses the results and concludes.

\section{Literature}

There are three strands of literature relevant for our study: the literature on rent-seeking, initiated by Tullock (1967) and Krueger (1974), studies of political business cycles, and studies of campaign contributions.

Presidential elections are clearly of interest for rent-seekers, as the president and the executive branch he leads have strong and direct control over budget spending and political priorities-setting that in turn allow interest groups to extract rents $^{1}$ - be it, e.g., agricultural or industrial sectors seeking protection from foreign competition, the defense industry that profits from armament programs and wars, or special interest groups that seek privileges for their members. The ongoing and intense debate whether politicians actually are influenced by their contributors, or whether contributors support only those candidates which are known

\footnotetext{
${ }^{1}$ Contributions are of course also given to provide information to voters, but this need not be the only reason (see, e.g., Austen-Smith 1987; Mueller and Stratmann 1994; Prat 2002; Coate 2004).
} 
to favor their interests cannot be answered by our data. ${ }^{2}$ We are, however, able to identify whether contributors were able to extract rents once the candidate they supported had won, and we can quantify these rents by calculating the abnormal returns of the asset of a contributing company. We agree with Lott (2000), who argues that the growth in campaign contributions can be attributed to rent seeking, and when larger rents are available interest groups will spend more to reap them. This is also supported by the literature identifying the industries that actually form PACs and contribute to election campaigns: especially those industries where the government is an important customer, heavily regulated industries, and concentrated industries (where the benefits of rents are also concentrated; see Pittman 1988; Zardkoohi 1988; Grier and Munger 1994; Hart 2001).

On the macroeconomic level, studies of political business cycles pioneered by Nordhaus (1975) and Rogoff (1990) usually aim to measure (i) whether a strong macroeconomic development favors the incumbent, and (ii) whether the election of a candidate influences the stock market. There is broad consensus on the first question - a healthy economy undoubtedly increases the chances of reelection for an incumbent candidate or party. On the second question data past 1927 show that the US-stock market performed better under Democratic presidents, than under Republicans (e.g., Santa-Clara and Valkanov 2003). However, Nofsinger (2007) shows that over a longer horizon (since 1828) there is no statistically sig-

\footnotetext{
${ }^{2}$ See Mueller (2003) and Stratmann (2005) for literature overviews and, e.g., Bronars and Lott (1997), Lott (2000), Ansolabehere et al. (2003), and Coate (2004) for evidence that money flows to candidates known to favor an interest group's opinions. Stratmann (2002) and Coate (2004) argue that candidates can be influenced by contributors, an outcome that is supported in theoretical models by Grossman and Helpman $(1994 ; 1996)$. However, all of this literature concentrates on congressional votes rather than on policymaking at the presidential level.
} 
nificant difference in stock returns between presidencies of the two parties.

Instead of looking at the overall economy we explore whether stock prices of contributing companies perform differently after a presidential election. Schwert (1981) was the first to recommend the use of stock prices as a means of quantifying the impact of policy changes. Jayachandran (2006) examines stock prices after Senator Jeffords left the Republican party in May 2001, thereby tipping control of the US Senate to the Democrats. Looking at soft money contributions in the previous election cycle she finds that for each $\$ 250.000$ given to the Republicans a company lost $0.8 \%$ of its market capitalization. She concludes that "shifts in political power have a large effect on the market value of firms" (Jayachandran 2006: 398). We take up this point and investigate the events in US politics that offer the clearest and most important "shifts in political power" - the presidential elections. We focus on contributions by listed corporations only, as the effect of changes in political power should be visible in the stock prices. While Cooper et al. (2008) report that the switch of congressional control had no significant influence on the stock returns of companies classified as leaning towards one of the two parties, we focus on presidential elections. Looking at only one election - the presidential election in 2000 - Knight (2006) and Goldman et al. (2009) find that listed companies aligned with the Republicans performed better than Democraticleaning companies after the election of George W. Bush. Hibbs (1987), Fair (1988), Erikson (1989), and Alesina and Roubini (1992) also focus on presidential rather than congressional election outcomes. While these studies focus on the economy in general, Herron et al. (1999) move towards the micro level by analyzing 74 different industry sectors. They find that 15 of these sectors were impacted significantly by the outcome to of the 1992 presidential election. Similarly, Roberts (1990) finds that the performance of a portfolio of defense companies 
correlated positively with the likelihood of Ronald Reagan becoming president in 1980 . We continue this trend towards the micro level by looking at individual companies.

\section{Data}

We look at the four presidential elections from 1992 to $2004 .^{3}$ We collect contribution data for the two years before an election and explore effects on the stock returns in the two post-election years. ${ }^{4}$ Therefore we use campaign contribution data from 1990-1992, 19941996, 1998-2000, and 2002-2004. Stock market data are collected for 1992-1994, 1996-1998, 2000-2002 and 2004-2006.

\subsection{Campaign contribution data}

Figure 1 presents the development of total campaign contributions for the presidential elections since 1992 . We see that total contributions increased by $18 \%$ to $43 \%$ from one election to the next and that the Republicans always raised more money than the Democrats. Ansolabehere et al. (2003) find that overall contributions as a share of GDP have remained fairly stable since 1912. Our data confirm this for the period 1990-2004, as overall contributions grew by a nominal annual rate of $5.4 \%$, compared to $5.0 \%$ for the U.S. economy.

\footnotetext{
${ }^{3}$ We have to limit our study to this period, as until 1991 parties did not have to report "soft money" contributions, so it was literally untraceable (Nelson 2000). As we need to assign contributions specifically to companies, for our analysis elections before 1991 cannot be included in our analysis.

${ }^{4}$ We chose a two-year time horizon for stock returns, as after the mid-term elections the observation window for the next contribution period starts and non-overlapping windows are highly desirable for the statistical analysis. Total contributions include third-party candidates as well. However, the median contribution to third parties equals $0.08 \%$ of total contributions and thus have virtually no influence on our results.
} 
However, corporate contributions grew much faster than overall contributions: combined donations by the Top-100 listed corporate contributors in each election cycle increased from $\$ 53.5$ million in the $1990-1992$ election period to more than $\$ 128$ million in the years 2002 2004 - an annualized growth of $7.5 \% .^{5}$

The largest corporate contribution per election cycle in our sample increased even more - from $\$ 1.89$ million to $\$ 6.74$ million - an annualized growth of $11.2 \%{ }^{6}$ This growth rate even dwarf the S\&P500's increase of $8.8 \%$ per year in the same period. ${ }^{7}$

Insert Figure 1 about here

For each presidential election we take 100 companies contributing the most to the two parties combined. ${ }^{8}$

\subsection{Stock market data}

To measure the effect of political events on the value of a company we have to focus on the post-election shift in company value. We do not need to develop new measures or proxies for

\footnotetext{
${ }^{5}$ Lott (2000) attributes strong growth in contributions to large rents. Maniadis (2009) argues that such contributions, especially by corporations, are important to ensure that politicians do not renege on their promises to support a business-friendly environment.

${ }^{6}$ Here the issue of contribution limits becomes relevant, as, e.g., in an empirical study Stratmann and Aparicio-Castillo (2006) find that the margin of victory for the winning candidate declined in races where there was a spending limit. However, Daniel and Lott (1997) and Lott (2006) argue in the opposite direction.

${ }^{7}$ All growth rates are nominal. Sources: Bureau of Economic Analysis, Thomson Datastream, and Federal Election Commission for GDP, S\&P 500, and campaign contribution data, respectively.

${ }^{8}$ Other studies sometimes take each company that contributed, no matter how much (up to 1,200 companies), rather than focusing on the largest contributors. However, we think this might distort results, as only really large contributions should have an influence. By taking all contributions, some papers assign the same weight to each contribution, no matter whether it was $\$ 1,000$ or $\$ 5$ million (Aggarwal et al. 2007).
} 
that, as the stock price on an efficient market already is a measure of company value. If the stock market is at least semi-strong form efficient, it aggregates traders' opinions about the value of a company and therefore reflects all publicly available information about it (Hayek 1945; Fama 1970, 1991).

Daily stock prices (adjusted for dividends and splits) and market capitalization were collected from Thomson Datastream for the period November 6th 1992 to November 7th 2006. Time series on the CRSP-performance-index and on the Fama/French-factors (Fama and French 1993), including the Carhart (1997) momentum factor, were taken from Kenneth French's data library. ${ }^{9}$

\section{Research questions and method}

\subsection{Research question 1: Company perspective - Did the pro- portion given to the winner and the total contribution have predictive power?}

With the first research question we concentrate on patterns in contributions to test for abnormal returns. To estimate the relationship between company $i$ 's campaign contributions during the election campaign period and its stock price after the election, we lag our contribution-related variables by one election cycle. For example, we relate company $i$ 's campaign contribution from the day after the mid-term election in November 1998 until the day before the presidential election in November 2000 to company $i$ 's performance from

\footnotetext{
${ }^{9}$ http://mba.tuck.dartmouth.edu/pages/faculty/ken.french/data_library.html.
} 
the day after the election in November 2000 until the day before the mid-term election in November 2002. In the subsequent analysis we examine companies along two dimensions:

- the relative preference for one candidate over the other measured by PERCDIFF and

- the overall contribution relative to market capitalization measured by CTOT.

With PERCDIFF we measure company i's relative preference of one candidate over the other, irrespective of the total amount contributed. PERCDIFF ${ }_{i, j}$ is the difference in the percentage of company $i$ 's contribution given to the winner $\left(\frac{\mathrm{CGOV}}{\mathrm{TOTAL}}\right)$ and the percentage given to the losing candidate $\left(\frac{\text { COPP }}{\text { TOTAL }}\right)$ in election cycle $j$,

$$
\operatorname{PERCDIFF}_{i, j}=\frac{\mathrm{CGOV}_{i, j}}{\mathrm{TOTAL}_{i, j}}-\frac{\mathrm{COPP}_{i, j}}{\mathrm{TOTAL}_{i, j}}
$$

$\mathrm{CGOV}_{i, j}$ and $\mathrm{COPP}_{i, j}$ define company $i$ 's contribution to the winning and losing candidate in election $j$ and TOTAL $_{i, j}$ stands for the total contribution given by company $i .^{10}$

While PERCDIFF measures the commitment to one of the two candidates, our second variable CTOT picks up the overall political involvement of a company. This variable is important to account for companies like Citigroup or AT\&T, which were among the largest contributors in each election, but split their contributions equally among the two candidates. In such cases, PERCDIFF is close to zero. We interpret this as a "diversification" to ensure that contributions have access to the government irrespective of the election outcome. This

\footnotetext{
${ }^{10}$ We classify "government" and "opposition" as the party holding the presidency and the other party respectively, i.e., the Democrats under Clinton formed the government from 1992-2000 and the Republicans under George W. Bush did so during 2000-2008, the last two years of which are beyond the end of our sample.
} 
explanation is supported by Ansolabehere et al. (2003), p. 126 who state that "campaign contributions are one way to improve the chances of getting to see the legislator about matters of concern to the group."

To compute $\mathrm{CTOT}_{i, j}$ we divide each company $i^{\prime} s$ contribution by its market capitalization and take the log of this number. A contribution of $\$ 5$ million signals very high political involvement when given by a small company with market capitalization below $\$ 1$ billion, while it is "peanuts" for Microsoft with a market capitalization of more than $\$ 200$ billion. As campaign contributions of companies are increasing over time, we apply the following transformation to arrive at the final form of $\mathrm{CTOT}_{i, j}$ which is:

$$
\mathrm{CTOT}_{i, j}=\log \frac{\frac{\operatorname{TOTAL}_{i, j}}{\overline{\operatorname{TOTAL}_{j}}}}{\frac{\mathrm{MCAP}_{i, j}}{\overline{\mathrm{MCAP}_{j}}}} .
$$

We divide each contribution by the average contribution in the corresponding election cycle. The same is done for market capitalization, as this variable also increased several-fold during our sample period.

As we have several observations over time for most companies, we apply a panel regression model with PERCDIFF and CTOT as independent variables. To generate the appropriate data set we first set up an OLS-estimation for the stock return of company $i$ using (i) the CAPM (Capital Asset Pricing Model) developed by Sharpe (1964) and Lintner (1965), and (ii) Carhart's (1997) four-factor model according to equations 3 and 4, respectively. Fama and French (1993) show that not only the market return, but also that two other factors (company size (SMB) and book-to-market ratio (HML)) have explanatory power. Carhart (1997) extends their model to a four-factor model by adding a momentum factor 
$(\mathrm{MOM})$ :

$$
\operatorname{RTRF}_{i, t}=\alpha+\beta_{1} \operatorname{RMRF}_{i, t}+\beta_{A R_{1}} \operatorname{RTRF}_{i, t-1}+\epsilon_{i, t}
$$

$$
\begin{aligned}
\operatorname{RTRF}_{i, t} & =\alpha+\beta_{1} \mathrm{RMRF}_{i, t}+\beta_{2} \mathrm{SMB}_{i, t}+\beta_{3} \mathrm{HML}_{i, t}+\beta_{4} \mathrm{MOM}_{i, t}+ \\
& +\beta_{A R_{1}} \mathrm{RTRF}_{i, t-1}+\epsilon_{i, t} .
\end{aligned}
$$

$\mathrm{RTRF}_{i, t}$ indicates the difference between company $i$ 's daily log-returns $\left(\mathrm{RT}_{i, t}\right)$ and the daily risk-free interest rate $\left(\mathrm{RF}_{t}\right)$, which is approximated by the monthly T-bill return. $\mathrm{RMRF}_{i, t}$ defines the daily excess log-return of a value-weighted performance index composed of all AMEX, NYSE and NASDAQ stocks (CRSP-Index) relative to $\mathrm{RF}_{t} . \mathrm{SMB}_{i, t}$ is the difference in returns between a portfolio of small stocks and a portfolio of large stocks. $\mathrm{HML}_{i, t}$ measures the difference in returns between a portfolio consisting of stocks with high book-to-market ratios and a portfolio of stocks with low book-to-market ratios. With $\mathrm{MOM}_{i, t}$ we include the momentum anomaly first reported by Jegadeesh and Titman (1993). MOM ${ }_{i, t}$ measures the difference of a portfolio consisting of past high-return stocks and a portfolio of past lowreturn stocks. ${ }^{11}$ Finally, we account for first-order autocorrelation by adding an AR(1)-term (Edmans et al. 2007).

\footnotetext{
${ }^{11}$ For a detailed description of all factors, see Fama and French (1993) and the website of Kenneth French: http://mba.tuck.dartmouth.edu/pages/faculty/ken.french/data_library.html. Note that the factors include all AMEX, NYSE and NASDAQ stocks.
} 
Let $\hat{\epsilon}_{i, t}$ denote a time series of daily residuals from equation 4 for stock $i$. We then calculate the two-year return during election cycle $j$ by summing up all residuals $\left(\hat{\epsilon}_{i, t}\right)$ to $T_{j}$ :

$$
\mathrm{y}_{i, j}=\sum_{t=1}^{T_{j}} \hat{\epsilon}_{i, t} .
$$

$T_{j}$ defines the number of trading days within election cycle $j$. To look at the development of abnormal stock returns over time after Election Day, we also calculate returns for both the first six and twelve months after the election. Therefore, we additionally set $T_{j}$ to 126 and 252 trading days, respectively. Earlier studies of this subject often focus on a very short time horizon, i.e., one day to one week. Goldman et al. (2009), for example, find that companies with boards that are connected to the Republicans significantly outperformed the market over the period of one to seven days after Election Day 2000, when Bush was elected president. We chose to look at the longer horizons of 6,12 , and 24 months, as, e.g., Aggarwal et al. (2007) argue that if donating to winners does represent an investment, positive effects should be persistent. Again, we apply the same lag structure regarding contributions and returns as in all other analysis in this paper.

Finally, we set up the following panel regression:

$$
\begin{aligned}
\mathrm{y}_{i, j} & =\alpha+\beta_{1} \operatorname{PERCDIFF}_{i, j-1}+ \\
& +\beta_{2} \operatorname{CTOT}_{i, j-1}+\epsilon_{i, j} .
\end{aligned}
$$


Note that we do not correct for cross-section fixed effects, since this would eliminate the very idiosyncratic growth rates of individual stocks we want to measure. We do not correct for period fixed effects either, as they are not significant. Instead, we use the White cross-section method to control for cross-section correlation and heteroscedasticity.

\subsubsection{Robustness checks}

To test the reliability of our model, we run three robustness checks each for the CAPM and the four-factor model with alternate definitions of our dependent and independent variables. First, to account for unsystematic risk we enter normalized returns $\left(\mathrm{NRT}_{i, j}\right)$ as the dependent variable by dividing the six-month, one-year, and two-year returns from equation 5 by their corresponding standard deviations $\left(\hat{\sigma}_{i, j}\right)$,

$$
\mathrm{NRT}_{i, j}=\frac{\mathrm{y}_{i, j}}{\hat{\sigma}_{i, j}}
$$

To arrive at $\hat{\sigma}_{i, j}$ we multiply the average daily standard deviation of stock $i$ 's residuals by the square root of the number of trading days of interest $T_{j}(126,252$, and approximately 500 respectively) in cycle $j$.

In the second robustness check we examine the reliability of the independent variable CTOT by regressing it against the unbenchmarked log of the total contribution $\log (\mathrm{CONT}) .{ }^{12}$

In the final robustness check we investigate the movement in stock prices of companies mostly contributing to the winning or losing candidate with two alternative independent variables. As contributions to the winner and loser increased severalfold over elections, we

\footnotetext{
${ }^{12} \mathrm{CONT}_{i, j}$ is calculated as the log of the total contribution of a company divided by its market capitalization on Election Day.
} 
apply the following transformation:

$$
\begin{aligned}
\text { CONT_WINNER }_{i, j} & =\frac{\mathrm{CGOV}_{i, j}}{\overline{\mathrm{CGOV}_{j}}} \\
\text { CONT_LOSER }_{i, j} & =\frac{\mathrm{COPP}_{i, j}}{\overline{\mathrm{COPP}_{j}}} .
\end{aligned}
$$

In particular, to compute CONT_WINNER ${ }_{i, j}$ we divide company $i$ 's contribution to the election winner $\left(\mathrm{CGOV}_{i, j}\right)$ by the average contribution to the winner $\left(\overline{\mathrm{CGOV}_{j}}\right)$ among all companies in cycle $j$. The same is done for contributions to the losing candidate, which is measured by CONT_LOSER $i, j$. Hence, with this robustness check we test whether our main specification in Section 4.1. masks the effects of contributing to the losing candidate. If both variables in equation 6 show positive coefficients, one could argue that large contributions, most of which go to the loser, yield abnormal returns for company $i$ as well. ${ }^{13}$ With this specification we take up this argument and analyze whether there is a positive relationship between contributing to the winner and abnormal returns and whether the opposite holds for contributions to the losing candidate. All other model parameters, such as the dependent variable and the coefficient covariance method, remain identical to the main model presented in Section 4.1.

\footnotetext{
${ }^{13}$ We thank one anonymous referee for pointing us to the idea of this test.
} 


\subsection{Research question 2: Investor perspective - Could abnormal returns be generated by picking stocks according to contri- bution data?}

While in research question 1 we focus on the company perspective, in research question 2 we explore whether an investor could have earned abnormal returns by selecting portfolios according to the two variables CTOT and PERCDIFF.

The empirical literature offers numerous examples where statistically significant abnormal returns are reported to justify an "anomaly", but once transaction costs are taken into account the significance often disappears. ${ }^{14}$ If an investor wanted to trade based on our results, only two transactions were necessary every two years for any stock $i$ - thus transaction costs play only a marginal role.

We form six value-weighted portfolios according to our two measures PERCDIFF and CTOT for each election cycle: ${ }^{15}$

- PERCDIFF30: Top 30 ranked stocks according to the variable PERCDIFF.

- PERCDIFF31_70: stocks ranked from 31 to 70 according to PERCDIFF.

- PERCDIFF71_100: stocks ranked from 71 to 100 according to PERCDIFF.

\footnotetext{
${ }^{14}$ Some examples where effects are reported include Lakonishok and Smidt (1988); Ariel (1990); Kohli and Kohers (1992); Kim and Park (1994). Malkiel (2003) and Marquering et al. (2006) claim that after controlling for transaction costs almost all of these "anomalies" fail to deliver positive abnormal returns.

${ }^{15}$ The same lag structure regarding contributions and returns is used as in the previous calculations. Note that a stock may be included in up to two of the six portfolios for a given election. For example, a company making a large total contribution and giving most to the Democrats before a Clinton victory could be included in the CTOT30 and PERCDIFF30 portfolios for that election.
} 
Three additional value-weighted portfolios are computed in the same way for CTOT, namely CTOT30, CTOT31_70, CTOT71_100.

Our last portfolio is composed of the Top-100 contributors during each election cycle (PF_Top100) to see whether all companies under investigation earn abnormal returns as a group. If they represent an unbiased sample of the market, their owners should not experience abnormal returns.

For research question 2 we use the CAPM and the four-factor model for performance measurement again:

$$
\begin{gathered}
\operatorname{RTRF}_{j, t}^{\mathrm{PF}}=\alpha+\beta_{1} \mathrm{RMRF}_{j, t}+\epsilon_{j, t} \\
\mathrm{RTRF}_{j, t}^{\mathrm{PF}}=\alpha+\beta_{1} \mathrm{RMRF}_{j, t}+\beta_{2} \mathrm{SMB}_{j, t}+\beta_{3} \mathrm{HML}_{j, t}+\beta_{4} \mathrm{MOM}_{j, t}+\epsilon_{j, t}
\end{gathered}
$$

To accommodate midterm elections, we measure the return only up to two years following Election Day. Therefore, we cannot run a simple OLS-regression, as our time series is not continuous. Instead, we apply a panel regression for each portfolio with the four elections as cross-sections $(j)$ and with 24 observations (months) over time $(t)$. We correct with the White period coefficient covariance method to account for arbitrary serial correlation and time-varying variances in the residuals.

We consciously chose the most rigorous and demanding methodology - the calendar-time portfolio approach with value-weights among the stocks - so any results we find can be considered highly reliable (see Fama 1998; Mitchell and Stafford 2000). 


\section{Results}

\subsection{Main result 1: The proportion given to the winner and the total contribution had predictive power}

In Section 4.1. we hypothesize that the two independent variables measuring (i) the commitment of a company to a candidate (PERCDIFF) and (ii) the log of the total contribution relative to company size (CTOT) should have a significant positive influence on its stock market performance.

As can be seen in Table 1, PERCDIFF is positive for all observation periods for the aggregate data set. With the CAPM it is significant for the six- and 12-month horizons, while with the four-factor model it is significant on the 24-month horizon. As an illustration: A company which contributed only to the winning candidate on average outperformed a company that contributed equally to both candidates by 5.5 (4.0) percentage points in the first year after an election using the CAPM (four-factor model).

\section{Insert Table 1 about here}

Looking at the Clinton and Bush presidencies separately we find highly significant coefficients for Bush with the CAPM on all horizons, and positive but only partly significant coefficients for Clinton. Under Clinton a company contributing only to him outperformed a company giving equally to both candidates by 6.8 (8.2) percentage points in the first year after an election with the CAPM (four-factor model). Under Bush the difference even reached 12.3 (4.4) percentage points in the twelve months after an election.

For CTOT we find even more significantly positive coefficients in the aggregate data for 
all observation periods. To illustrate our results we compare two hypothetical companies with average market capitalization but with different total contributions. Whereas company A gives four times the average contribution, company B contributes only the average donated by the Top-100 listed corporations. Company A would have outperformed company B by, on average, 12.9 (9.0) percentage points in the first year after the election when the CAPM (four-factor model) is applied. The results for Clinton and Bush are quite consistent with positive coefficients on all observations, with 10 of the 12 coefficients being significant on the 1\%- or 5\%-level. Especially the results for Bush are economically highly significant, as company A outperforms company B by 17.1 (11.4) percentage points in the first twelve months following Election Day when the CAPM (four-factor model) is used. Looking at the two-year horizon the difference in returns reaches 30.3 (23.4) percentage points. ${ }^{16}$ Rentseeking under Bush may have been more effective than under Clinton for two reasons: First, his party also held control of the House of Representatives for the first six of his eight years in office and of the Senate for four years, allowing him to push through some controversial decisions relying solely on the votes of Republicans. Clinton, by contrast, had to negotiate compromises - while by nature never fully satisfying any side - with a Republican-controlled House and Senate after the mid-term elections 1994. The second reason may be the wars in Afghanistan and Iraq, and more broadly the "war on terror", that increased government spending, especially on defense. ${ }^{17}$ Higher government spending, especially discretionary

\footnotetext{
${ }^{16}$ We also ran an OLS-regression for each election cycle separately and found similar results.

${ }^{17}$ Under Clinton defense spending as a percentage of GDP fell from 4.78\% in 1992 to 3.00\% in 2000. Under Bush it increased to $4.28 \%$ of GDP in 2008. In nominal terms defense spending under Clinton remained almost unchanged slightly below $\$ 300$ billion, while it more than doubled to $\$ 616$ billion under Bush. Source: Office of Management and Budget, Executive Office of the President; the data was extracted from the Google
} 
decisions, e.g., which weapons to buy, give political decision makers more scope to "reward" supporters - especially as the defense industry strongly supported Bush during his election campaign.

We conclude that CTOT was the more decisive factor in generating abnormal returns from 1992 to 2006. Furthermore, as can be seen from PERCDIFF, companies that strongly supported the winner of the election outperformed companies supporting the losing candidate. Both factors were economically and statistically more significant during the Bush presidency.

\subsubsection{Robustness checks}

As can be seen from Tables A1 (CAPM) and A2 (four-factor model) in the Appendix, our results are robust to changes in the dependent as well as the independent variables. In our first robustness check we replace abnormal returns by the normalized returns $\left(\mathrm{NRT}_{i, j}\right)$ as shown in equation 7 . The significant results we find are very similar to what we find in our original analysis for the aggregate data set and for both the Clinton and Bush subsamples.

\section{Insert Table A2 about here}

In the second robustness check we change the independent variable CTOT, leaving all other things unchanged. Specifically, $\log (\mathrm{CONT})$ is not transformed, i.e., this number is not benchmarked on the respective average contribution per election cycle. In the aggregate and in both subsamples our main results hold in all respects.

In the third robustness check (see Table A3 for details) one can see that the coefficients of contributing to the winner (CONT_WINNER) are clearly positive and mostly significant public data explorer. 
on an aggregate level. In contrast, the coefficients of CONT_LOSER are all negative, some significantly. These results provide further evidence that companies' stock market performances after the elections were better the more a company donated to the election winner. In contrast, the more a company donated to the election's loser, the worse its post-election stock market performance. Our main specification in this article does not mask the possible effects of contributing to the loser. A large total donation which is mainly given to the losing candidate does not yield abnormal positive returns. Again, these main results hold in both subsamples of Clinton and Bush in all respects.

Insert Table A3 about here

\subsection{Main result 2: Picking stocks according to contribution data generated abnormal returns for investors}

As outlined in Section 4.2. we now focus on the investor perspective and examine the performance of portfolios formed according to contribution data.

\subsubsection{Performance of a portfolio of all 100 companies}

Before we outline the results of the sub-portfolios we examine our whole data sample and calculate whether the returns to the largest 100 contributors as a group differs from the market return. In Table 2 we apply the CAPM and the four-factor-model of equations 10 and 11 to examine whether the monthly abnormal returns (alphas) differ significantly from zero.

Insert Table 2 about here 
Applying the CAPM (column 1) we find no significant results for the aggregate sample. The same holds when we look at the Clinton and Bush presidencies separately (columns 3 and 5 respectively). Thus, the return to the 100 largest contributors as a group is not different from the market return.

When we apply the four-factor-model we also find no significant results (columns 2, 4, and 6). The coefficients for SMB and HML indicate that our sample includes mainly large cap stocks with high book-to-market ratios. This confirms the observation of Cooper et al. (2008), that mostly large companies contribute to political campaigns.

We thus conclude that the returns to major contributors as a group were not distinguishable from the market - no matter whether we use the CAPM or whether size, book-to-market ratio, and momentum are accounted for with the four-factor model. This is in line with the efficient market hypothesis (EMH) and indicates that our sample is not biased.

\subsubsection{Performance of sub-portfolios}

In what we consider one of the key analyses of the paper we measure the performance of portfolios formed according to the two variables PERCDIFF and CTOT. Figure 2 illustrates the results. In the top panels we sort our companies according to the variable PERCDIFF in each election cycle and calculate a value-weighted portfolio for the corresponding Top 30 stocks (solid line; PERCDIFF30; the 30 clearest supporters of a candidate) and a value-weighted portfolio for the corresponding stocks with ranks 71 to 100 (dotted line; PERCDIFF71_100 - the 30 companies leaning most towards his opponent). The figures present the cumulative abnormal returns to these portfolios compared to the CRSP-Index over the two years after an election. In the bottom panels we sort according to the variable CTOT in each 
election cycle. Again, the figures present the cumulative abnormal returns compared to the CRSP-Index of the CTOT30- and CTOT71_100-portfolios.

Insert Figure 2 about here

The two left panels, presenting the results for Clinton, look fairly similar. In both figures the PERCDIFF30- and CTOT30-portfolios accumulate positive abnormal returns, while the PERCDIFF71_100- and CTOT71_100-portfolios accumulate negative abnormal returns in the 20 months after the election, for a net difference of up to 20 percentage points. Therefore, large contributors, especially the strongest supporters of Clinton, performed very well after his election victories.

The results for Bush are presented in the right panels. We see immediately that the differences in returns between the portfolios are larger than they are for Clinton. Comparing the two panels we find that the development is quite similar in the first year after the election, where the largest contributors according to both measures outperform the smallest contributors by up to $25 \%$. In the second year the two figures differ somewhat: while the difference between the PERCDIFF30- and PERCDIFF71_100-portfolios remains quite stable at roughly 20 to 25 percentage points, the difference between the CTOT30- and CTOT71_100-portfolios grows over the whole observation period to more than 45 percentage points. This corroborates the comparatively greater predictive power of CTOT during the Bush years that was already evident in the panel regressions reported above.

Especially in the top panels the two lines for the CTOT30- and CTOT71_100-portfolios move in opposite directions most of the time. Looking for an economic interpretation, this suggests that in cases of direct competition, e.g., for contracts, contributors to the winner 
have an edge over contributors to the eventual loser of an election. For example, when Boeing and Lockheed are competing for a large contract to supply new airplanes to the army, the success of one company is necessarily the loss of the other.

The story told in the bottom panels, contrasting the performance of the largest donors to those who contributed comparatively little, is a bit different. Here the largest contributors do very well, especially under Bush, while those who gave comparatively little (CTOT71_100) earn returns equal to the market (under Clinton) or slightly below it (under Bush). This suggests, that those who gave a lot gained, e.g., access to politicians to present their views (supposedly one of the main reasons for donating), while those who gave little did not have such access and performed just as everybody else in the market did (or a bit worse under Bush).

Turning from the graphical to the econometric analysis, Table 3 presents results for the first 24 (top three panels), 12 (panels 4 to 6 ) and six (last three panels) months after each election. The first two columns show the alphas of the PERCDIFF30 and PERCDIFF71_100portfolios, i.e., the companies with the highest 30 values for PERCDIFF and with the lowest 30 values, respectively. ${ }^{18}$ The first line of each panel shows the monthly CAPM-alpha, the second line the respective p-value, the third line the monthly alpha according to the fourfactor model, and the fourth line the respective p-value. The right two columns present the same data for portfolios formed according to CTOT.

Insert Table 3 about here

\footnotetext{
${ }^{18}$ We do not show the PERCDIFF31_70- and CTOT31_70-portfolios in this table, as they are of minor interest and are hardly ever significant, which is in line with our expectations.
} 
Looking first at the CAPM-alphas one can see that in the first column of Table 3 all nine monthly CAPM-alphas of the PERCDIFF30 portfolios are positive (five of them significant) with values up to $0.76 \%$ per month. This means that abnormal annual returns of up to 9.4\% could have been earned when investing in the 30 companies with the largest share of contributions to the winning candidate. Also in line with our prediction, eight out of the nine PERCDIFF71_100 portfolios show negative CAPM-alphas of between $-0.58 \%$ and $-0.15 \%$ per month. Three are significant on the $1 \%$ level, stressing the economic and statistical relevance of the results. When we turn to the alphas of the PERCDIFF-portfolios according to the four-factor model most significances disappear, as this model already accounts for size, book-to-market ratio, and momentum.

In the right two columns, the results of CTOT, which deliver much more significant results on our first research question, are reported. We find very consistent and clear results for the CAPM: all CTOT30-alphas for the aggregate and the separate data samples are positive and significant on the $1 \%$ level with alphas between $0.26 \%$ and $1.46 \%$ per month. This translates into abnormal returns of up to $19.0 \%$ per year. Also in line with our predictions the alphas of all CTOT71_100-portfolios are negative, with five of the nine values are significant on the $1 \%$ - or $5 \%$-level.

The results are somewhat weaker when the four-factor model is applied. We still find seven of nine alphas of the CTOT30-portfolios to be positive, five of them significant, most of them on the 1\%-level. However, here we also have one significant negative alpha for the 12-month horizon under Clinton.

Taking a look at both presidencies separately we find that under Clinton six out of twelve and under Bush eight out of twelve CTOT30- and CTOT71_100-portfolios are significant on 
the 1\%-level with the predicted sign (CAPM and four-factor model alphas).

We conclude that forming portfolios according to PERCDIFF and especially according to CTOT allowed investors to earn significant abnormal returns, while those who invested in a portfolio of the companies with the lowest values of PERCDIFF and CTOT suffered negative abnormal returns.

\section{Conclusion and discussion}

By setting the national agenda, proposing an annual budget, and defining policies on defense, trade, environment and defining public policies and myriad other programs, the President of the Unites States and his administration affect business life in many ways. This makes presidential election campaigns natural areas of rent-seeking behavior by companies. We explored whether the pre-election campaign contribution of public listed companies were related to their stock market performances after the elections. We found that companies that had supported the elected president during his campaign, been generous in their contributions to him, or both, enjoyed positive and significant abnormal returns. This suggests that there were rents to be extracted.

Specifically we found that both (i) the percentage of contributions given to the winner in a presidential election and (ii) the log of the total contribution (divided by market capitalization) significantly increased a company's abnormal stock market return in the two years after an election in the period 1992-2006. Of the two factors, the second led to larger differences.

For example, a company contributing only to the eventual winner of a presidential election 
would have outperformed a company splitting its contribution equally across both candidates by 5.5 percentage points in the first year after the election when the CAPM is applied and by 4.0 percentage points using Carhart's (1997) four-factor model. On the other hand, by comparing two companies with equal market capitalization but different total contributions we found the larger total contributor (giving four times the average) to outperform the smaller total contributor (giving the average) by 12.9 (9.0) percentage points when using the CAPM (four-factor model) in the twelve months after Election Day. Both variables had a stronger effect under Bush. We reason that two factors help to explain why most effects found were stronger under Bush than under Clinton: the first one is that Bush mostly had a Republican Congress to deal with, while Clinton faced an opposition-dominated House and Senate for six of his eight years in office. The second reason was probably the "war on terror", mostly fought in Afghanistan and Iraq. This war increased government spending, especially on defense. This spending rewarded campaign donors from the defense industry, which had not been expected before the election.

We then formed hypothetical portfolios of the 30 largest contributors according to (i) the percentage of contributions given to the winner in a presidential election and (ii) the log of the total contribution (divided by market capitalization) and analyzed whether abnormal returns would have been earned. For instance, an investor selecting a portfolio according to (i) would have earned significant abnormal returns of up to $6.6 \%$ annually during the first year after an election. Investing in a portfolio formed according to (ii) would have yielded abnormal annual returns of up to $15.5 \%$ for the same observation period.

Do the results contradict the efficient market hypothesis (EMH)? Not necessarily. When we compared the findings from the CAPM with the four-factor model, most coefficients 
were smaller in the latter model. However, even when we control for four factors, some variations in the returns can still be explained by the political variables presented in this paper. Abnormal returns accumulated over months or even two years after Election Day, indicating that the market underestimated the effect of government decisions on the stock market value of companies. Campaign contributions are a proxy, but not a perfect one, for access to politicians or the ability to extract rents from the political process. Ongoing lobbying activities, for which spending is some 10 times larger than for the election campaign, can alter access and chances for successful rent-seeking. Thus, it may be that the market is underestimating the importance of access (analyst reports rarely talk about political access), or ongoing lobbying activities may lead to further abnormal returns.

To conclude, we want to stress that our results do not necessarily mean that politicians deliver policies that companies "bought" with their contributions. Rather, the general policies implemented by an administration may suit a firm - e.g., President Bush's decisions not to sign the Kyoto-protocol, to allow drilling in some of Alaska's environmentally sensitive areas, and to go to war in Iraq have all helped oil companies. However, they were not necessarily designed to help them, but rather reflected Bush's convictions and attitudes. At the same time it would be foolish to assume that access to politicians should not have any influence on company performance.

\section{Acknowledgements}

We thank Michael Hanke, Florian Hauser, Thomas Stoeckl, Shyam Sunder, and participants at seminars at the University of Innsbruck and at Yale University for helpful comments. We 
would also like to thank the Editor and two anonymous referees for very helpful comments and suggestions. Daniel Kleinlercher provided excellent research assistance. 


\section{References}

Aggarwal, R., Meschke, F. and Wang, T. (2007). Corporate political contributions: Investment or agency?

Alesina, A. and Roubini, N. (1992). Political cycles in oecd economies, Review of Economic Studies 59 (4): 663-688.

Ansolabehere, S., de Figueiredo, J. and Snyder, J. M. (2003). Why is there so little money in us politics?, Journal of Economic Perspectives 17(1): 105-130.

Ariel, R. A. (1990). High stock returns before holidays: Existence and evidence on possible causes, The Journal of Finance 45 (5): 1611-1626.

Austen-Smith, D. (1987). Interest groups, campaign contributions and probabilistic voting, Public Choice 54: 123-139.

Bronars, S. and Lott, J. (1997). Do campaign donations alter how a politician votes? or, do donors support candidates who value the same things?, Journal of Law and Economics 40: $317-350$.

Carhart, M. M. (1997). On persistence in mutual fund performance, The Journal of Finance 52(1): $57-82$.

Coate, S. (2004). Political competition with campaign contributions and informative advertising, Journal of the European Economic Association 2(5): 772-804.

Cooper, M., Gulen, H. and Ovtchinnikov, A. (2008). Corporate political contributions and stock returns, Working paper . 
Daniel, K. and Lott, J. (1997). Term limits and electoral competitiveness: Evidence from california's state legislative races, Public Choice 90: 165-184.

Edmans, A., Garcia, D. and Norli, O. (2007). Sports sentiment and stock returns, The Journal of Finance 62 (4): 1967-1998.

Erikson, R. (1989). Economic conditions and the presidential vote, American Political Science Review 83 (4): 567-573.

Fair, R. (1988). The effect of economic events on votes for president: 1984 update, Political Behavior 10 (2): 168-179.

Fama, E. F. (1970). Efficient capital markets: A review of theory and empirical work, The Journal of Finance 45: 383-417.

Fama, E. F. (1991). Efficient capital markets 2, The Journal of Finance 66: 1575-1616.

Fama, E. F. (1998). Market efficiency, long-term returns, and behavioural finance, Journal of Financial Economics 49: 283-306.

Fama, E. F. and French, K. (1993). Common risk factors in the returns on stocks and bonds, Journal of Financial Economics 33 (1): 3-56.

Goldman, E., Rocholl, J. and So, J. (2009). Do politically connected boards affect firm value?, Review of Financial Studies 22: 2331-2360.

Grier, K. and Munger, M. (1994). The determinants of industrial political activity 1978-1986, American Political Science Review 88: 911-926. 
Grossman, G. and Helpman, E. (1994). Protection for sale, American Economic Review 84(4): 833-850.

Grossman, G. and Helpman, E. (1996). Electoral competition and special interest policy, Review of Economic Studies 63(2): 265-286.

Hart, D. (2001). Why do some firms give? why do some give a lot?: High-tech pacs, 19771996, Journal of Politics 63: 1230-1249.

Hayek, F. A. v. (1945). The use of knowledge in society, The American Economic Review 35 (4): 519-530.

Herron, M., Lavin, J., Cram, D. and Silver, J. (1999). Measurement of political effects in the united states economy: A study of the 1992 presidential election, Economics 6 Politics 11 (1): 51-81.

Hibbs, D. (1987). The American Political Economy: Electoral Policy and Macroeconomics in Contemporary America, Harvard University Press. Cambridge, MA.

Jayachandran, S. (2006). The jeffords effect, Journal of Law and Economics 49 (2): 397-425.

Jegadeesh, N. and Titman, S. (1993). Returns to buying winners and selling losers: Implications for stock market efficiency, The Journal of Finance 48 (1): 65-91.

Kim, C.-W. and Park, J. (1994). Holiday effects and stock returns: Further evidence, Journal of Financial and Quantitative Analysis 29 (1): 145-157.

Knight, B. (2006). Are policy platforms capitalized into equity prices? evidence from the bush/gore 2000 presidential election, Journal of Public Economics 90 (4-5): 751-773. 
Kohli, R. K. and Kohers, T. (1992). The week-of-the-month effect in stock returns: The evidence from the sp composite index, Journal of Economics and Finance 16: 129-137.

Krueger, A. (1974). The political economy of the rent-seeking society, American Economic Review 64: 291-303.

Lakonishok, J. and Smidt, S. (1988). Are seasonal anomalies real? a ninety- year perspective, Review of Financial Studies 1 (4): 403-425.

Lintner, J. (1965). The valuation of risk assets and the selection of risky investment in stock portfolios and capital budgets, Review of Economics and Statistics 47 (1): 13-37.

Lott, J. (2000). A simple explanation for why campaign expenditures are increasing: The government is getting bigger, Journal of Law and Economics 43(2): 359-393.

Lott, J. (2006). Campaign finance reform and electoral competition, Public Choice 129 (3): 263-300.

Malkiel, B. G. (2003). The efficient market hypothesis and its critics, Journal of Economic Perspectives 17: 59-83.

Maniadis, Z. (2009). Campaign contributions as a commitment device, Public Choice 139(3): 301-315.

Marquering, W., Nisser, J. and Valla, T. (2006). Disappearing anomalies: A dynamic analysis of the persistence of anomalies, Applied Financial Economics 16 (4): 291-302.

Mitchell, M. L. and Stafford, E. (2000). Managerial decisions and long-term stock price performance, Journal of Business 73 (3): 287-329. 
Mueller, D. (2003). Public Choice III, Cambridge University Press.

Mueller, D. and Stratmann, T. (1994). Informative and persuasive campaigning, Public Choice 81: 55-77.

Nelson, J. A. (2000). The supply and demand of campaign finance reform, Columbia Law Review 100 (2): 524-557.

Nofsinger, J. R. (2007). The stock market and political cycles, Journal of Socio-Economics 36 (5): $734-744$.

Nordhaus, W. (1975). The political business cycle, Review of Economic Studies 42 (2): 169190.

Office of Management and Budget, Executive Office of the President (2011). URL: http://www.google.com/publicdata/explore?ds=z6tggkh2adod2s_\&ctype=1\&strai $l=f a l s e \& b c=d \& n s e l m=h \& m e t_{-}=$spendings\&hl $=$en\&dl $=e n$

Pittman, R. (1988). Rent-seeking and market structure: Comment, Public Choice 58: 173186.

Prat, A. (2002). Campaign spending with office-seeking politicians, rational voters, and multiple lobbies, Journal of Economic Theory 103: 162-189.

Roberts, B. E. (1990). Political institutions, policy expectations, and the 1980 election: a financial market perspective, American Journal of Political Science 34 (2): 289-310.

Rogoff, K. (1990). Equilibrium political budget cycles, The American Economic Review 80 (1): $21-36$. 
Santa-Clara, P. and Valkanov, R. (2003). The presidential puzzle: Political cycles and the stock market, The Journal of Finance 58, LVIII: 1841-1872.

Schwert, W. (1981). Using financial data to measure effects of regulation, Journal of Law and Economics 24 (1): 121-158.

Sharpe, W. (1964). Capital asset prices: A theory of market equilibrium under conditions of risk, The Journal of Finance 19(3): 425-442.

Stratmann, T. (2002). Can special interests buy congressional votes? evidence from financial services legislation, Journal of Law and Economics 41 (3): 85-113.

Stratmann, T. (2005). Some talk: Money in politics. a (partial) review of the literature, Public Choice 124(1): 135-156.

Stratmann, T. and Aparicio-Castillo, F. (2006). Competition policy for elections: Do campaign contribution limits matter?, Public Choice 127(1): 177-206.

Tullock, G. (1967). The welfare costs of traiffs, monopolies, and theft, Western Economic Journal 5: 224-232.

Zardkoohi, A. (1988). Market structure and campaign contributions: Does concentration matter? a reply, Public Choice 58: 187-191. 
Figures and Tables 

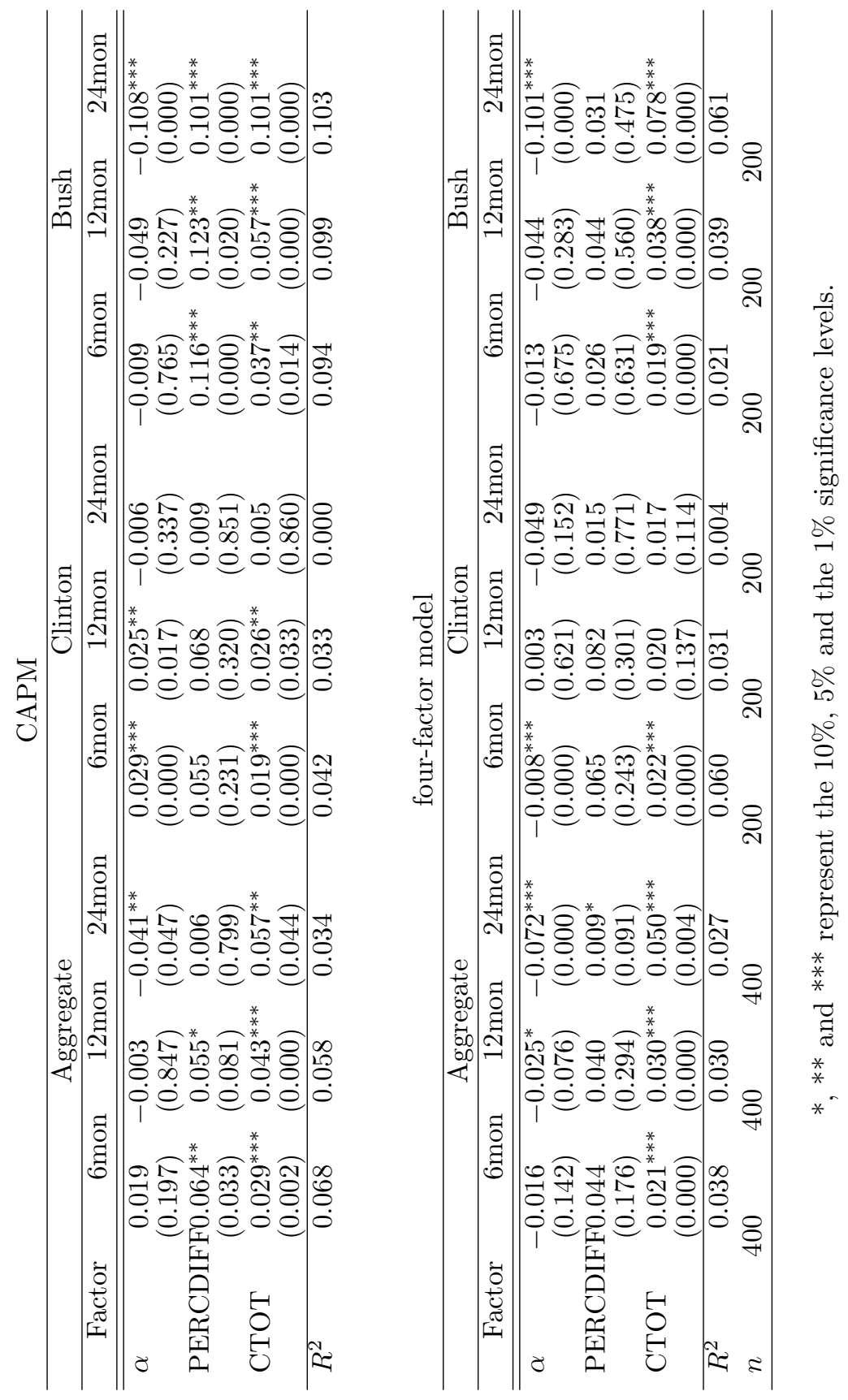

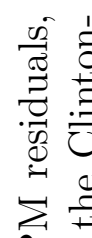

究

过

ڤై

응

里造.

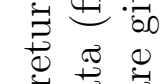

氶

离

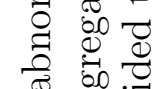

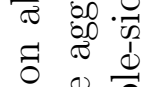

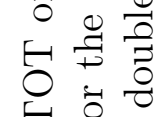

已

ฮี

压

己

단

पै

氙

कृ

寻荥

.0 .000

武者

ఏ્g

吾

0
0
0

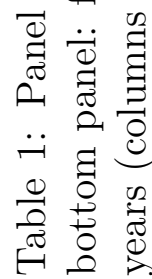




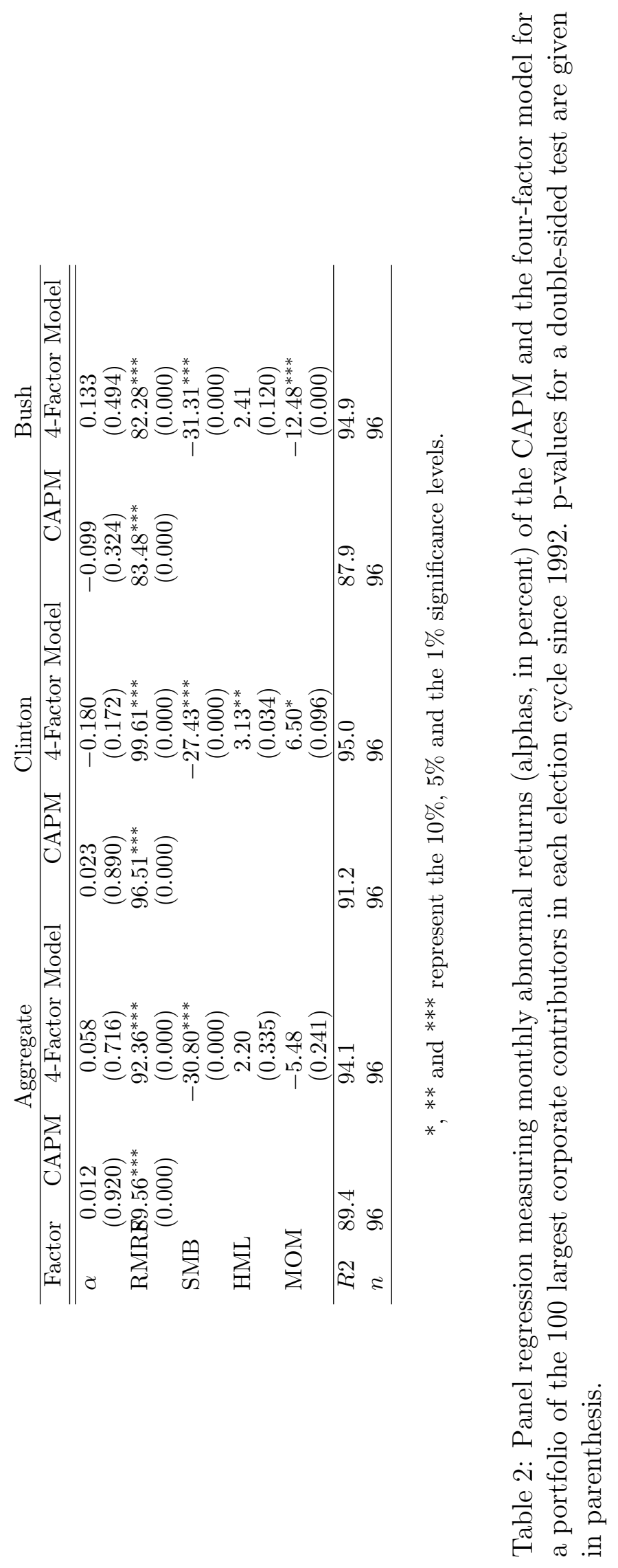




\begin{tabular}{|c|c|c|c|c|}
\hline & PERCDIFF30 & PERCDIFF71_100 & CTOT30 & CTOT71_100 \\
\hline $\begin{array}{l}\text { CAPM alpha } \\
\text { four-factor alpha }\end{array}$ & $\begin{array}{l}0.298^{* * *} \\
(0.006) \\
-0.131 \\
(0.510)\end{array}$ & $\begin{array}{l}-0.310^{* * *} \\
(0.000) \\
0.095 \\
(0.413)\end{array}$ & $\begin{array}{l}0.973^{* * *} \\
(0.000) \\
0.517^{* *} \\
(0.025)\end{array}$ & $\begin{array}{c}-0.159 \\
(0.329) \\
0.041 \\
(0.808)\end{array}$ \\
\hline \multicolumn{5}{|c|}{ Clinton } \\
\hline $\begin{array}{l}\text { CAPM alpha } \\
\text { four-factor alpha }\end{array}$ & $\begin{array}{l}0.096^{* * *} \\
(0.002) \\
-0.210 \\
(0.277)\end{array}$ & $\begin{array}{l}-0.148 \\
(0.345) \\
-0.212^{* * *} \\
(0.002)\end{array}$ & $\begin{array}{l}0.256^{* * *} \\
(0.000) \\
0.070 \\
(0.628)\end{array}$ & $\begin{array}{l}-0.043 \\
(0.868) \\
-0.204^{* * *} \\
(0.000)\end{array}$ \\
\hline \multicolumn{5}{|c|}{ Bush } \\
\hline four-factor alpha & $\begin{array}{c}0.070 \\
(0.645) \\
-0.173 \\
(0.465) \\
\end{array}$ & $\begin{array}{c}-0.280 \\
(0.317) \\
0.249 \\
(0.126) \\
\end{array}$ & $\begin{array}{l}1.225^{* * *} \\
(0.000) \\
0.746^{* * *} \\
(0.000) \\
\end{array}$ & $\begin{array}{c}-0.364^{* * *} \\
(0.000) \\
0.086 \\
(0.679) \\
\end{array}$ \\
\hline
\end{tabular}

Observation period: 12 months from Election Day - Aggregate data

\begin{tabular}{|c|c|c|c|c|}
\hline & PERCDIFF30 & PERCDIFF71_100 & CTOT30 & CTOT71_100 \\
\hline $\begin{array}{l}\text { CAPM alpha } \\
\text { four-factor alpha }\end{array}$ & $\begin{array}{l}0.535^{* * *} \\
(0.005) \\
0.239 \\
(0.637)\end{array}$ & $\begin{array}{c}-0.623^{* *} \\
(0.000) \\
0.004 \\
(0.974)\end{array}$ & $\begin{array}{l}1.209^{* * *} \\
(0.000) \\
0.740^{* *} \\
(0.021)\end{array}$ & $\begin{array}{c}-0.313^{* *} \\
(0.048) \\
0.276 \\
(0.296)\end{array}$ \\
\hline \multicolumn{5}{|c|}{ Clinton } \\
\hline $\begin{array}{l}\text { CAPM alpha } \\
\text { four-factor alpha }\end{array}$ & $\begin{array}{c}0.000 \\
(1.000) \\
0.110 \\
(0.838)\end{array}$ & $\begin{array}{c}-0.399^{*} \\
(0.087) \\
-0.179 \\
(0.277)\end{array}$ & $\begin{array}{l}0.310^{* * *} \\
(0.000)^{* *} \\
-0.364^{* * *} \\
(0.000)\end{array}$ & $\begin{array}{c}-0.444^{* * *} \\
(0.004) \\
0.154 \\
(0.495)\end{array}$ \\
\hline \multicolumn{5}{|c|}{ Bush } \\
\hline $\begin{array}{l}\text { CAPM alpha } \\
\text { four-factor alpha }\end{array}$ & $\begin{array}{c}0.136 \\
(0.537) \\
0.087 \\
(0.895) \\
\end{array}$ & $\begin{array}{c}-0.581 \\
(0.217) \\
-0.177 \\
(0.124) \\
\end{array}$ & $\begin{array}{l}1.396^{* * *} \\
(0.000)^{* * *} \\
1.124^{* * *} \\
(0.000) \\
\end{array}$ & $\begin{array}{l}-0.559^{* * *} \\
(0.001) \\
-0.051 \\
(0.831) \\
\end{array}$ \\
\hline
\end{tabular}

\begin{tabular}{|c|c|c|c|c|}
\hline & PERCDIFF30 & PERCDIFF71_100 & CTOT30 & CTOT71_100 \\
\hline $\begin{array}{l}\text { CAPM alpha } \\
\text { four-factor alpha }\end{array}$ & $\begin{array}{c}0.755^{*} \\
(0.000) \\
-0.544 \\
(0.432)\end{array}$ & $\begin{array}{c}-0.250 \\
(0.454) \\
1.036 \\
(0.124)\end{array}$ & $\begin{array}{c}1.238^{* * *} \\
(0.000) \\
0.180 \\
(0.627)\end{array}$ & $\begin{array}{c}-0.154 \\
(0.569) \\
0.389 \\
(0.434)\end{array}$ \\
\hline \multicolumn{5}{|c|}{ Clinton } \\
\hline $\begin{array}{l}\text { CAPM alpha } \\
\text { four-factor alpha }\end{array}$ & $\begin{array}{c}0.322 \\
(0.444) \\
-0.098 \\
(0.945)\end{array}$ & $\begin{array}{c}0.353 \\
(0.515) \\
1.236^{*} \\
(0.062)\end{array}$ & $\begin{array}{l}0.780^{* * *} \\
(0.000) \\
0.709^{* * *} \\
(0.010)\end{array}$ & $\begin{array}{c}-0.135 \\
(0.793) \\
0.254 \\
(0.493)\end{array}$ \\
\hline \multicolumn{5}{|c|}{ Bush } \\
\hline $\begin{array}{l}\text { CAPM alpha } \\
\text { four-factor alpha }\end{array}$ & $\begin{array}{l}0.396^{* * *} \\
(0.006)^{* *} \\
-1.448^{* *} \\
(0.024)\end{array}$ & $\begin{array}{c}-0.445 \\
(0.459) \\
0.321 \\
(0.439) \\
\end{array}$ & $\begin{array}{l}1.464^{* * *} \\
(0.001) \\
-0.292 \\
(0.361) \\
\end{array}$ & $\begin{array}{l}-0.505^{* * *} \\
(0.000) \\
-0.463 \\
(0.258)\end{array}$ \\
\hline
\end{tabular}

$*, * *$ and ${ }^{* * *}$ represent the $10 \%, 5 \%$ and the $1 \%$ significance levels.

Table 3: Monthly abnormal returns (alphas, in \%) of value-weighted portfolios formed according to PERCDIFF (left two columns) and CTOT (right two columns). p-values for a double-sided test are given in parenthesis. $R^{2}$ shows values between $75 \%$ and $95 \%$. 


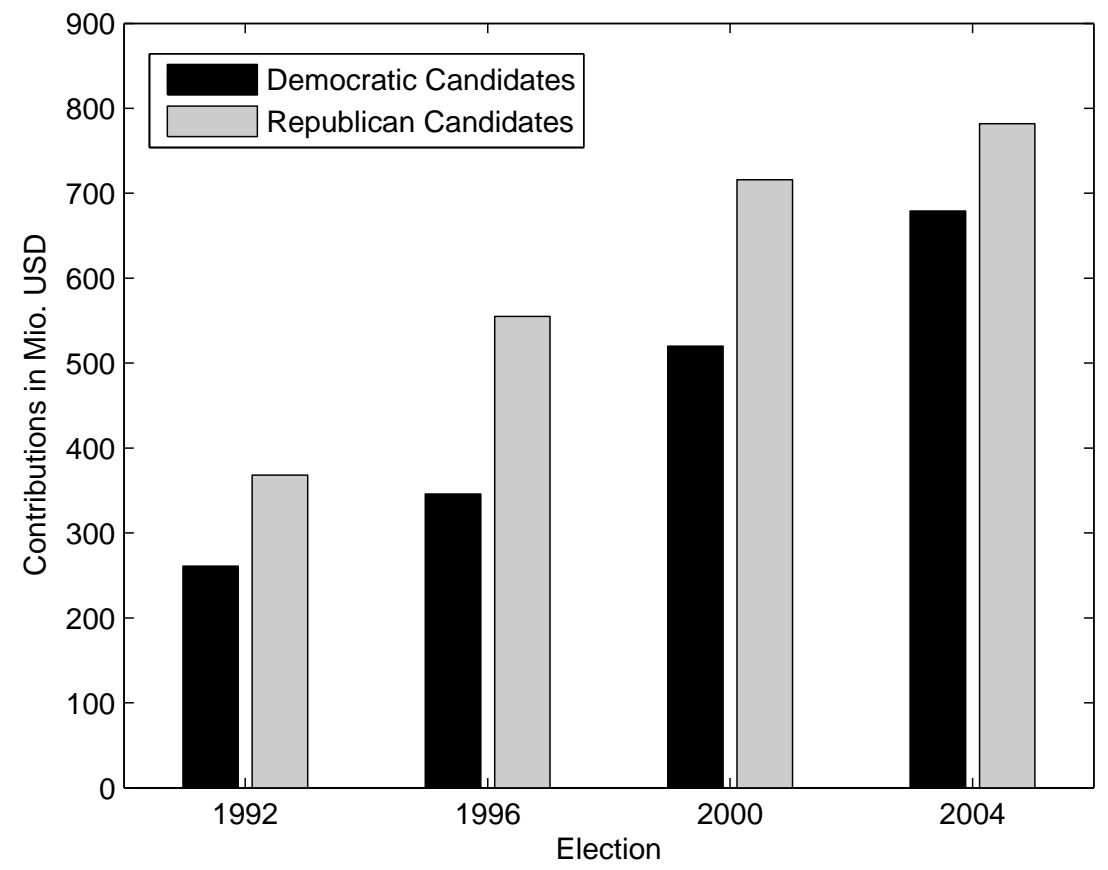

Figure 1: Development of total campaign contributions for the two years before a presidential election in the period 1992-2004. Source: Center for Responsive Government. 

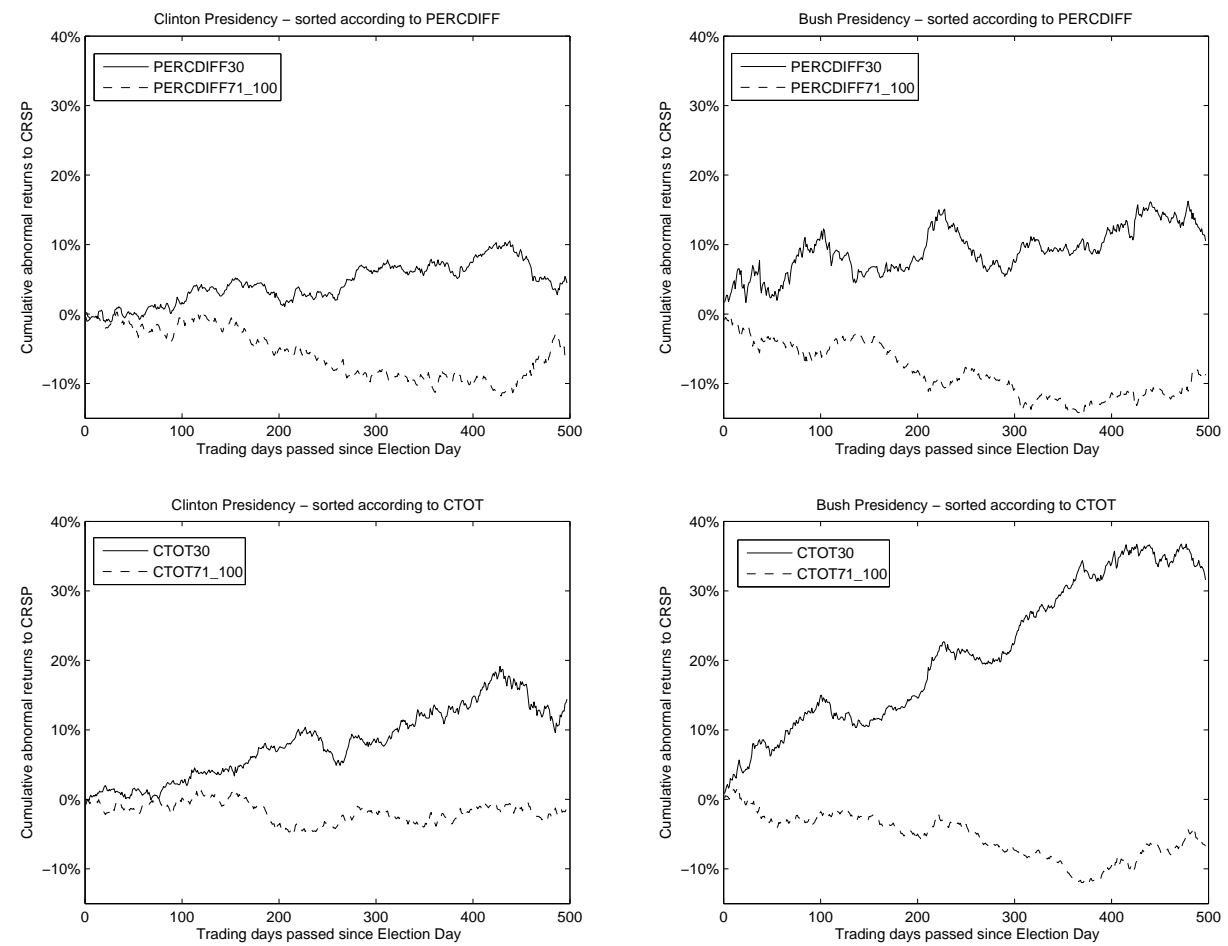

Figure 2: Cumulative abnormal returns of value-weighted portfolios composed of 30 stocks each compared to the CRSP-performance index. Top panels: Portfolio formation according to PERCDIFF with PERCDIFF30 (PERCDIFF71_100) containing the stocks ranked from 1 to 30 (71 to 100) in an election cycle. Bottom panels: Portfolio formation according to CTOT. The left panels show the development of cumulative abnormal returns over time during the Clinton presidency, while the right panels present the same data for the Bush presidency. 
Appendix 

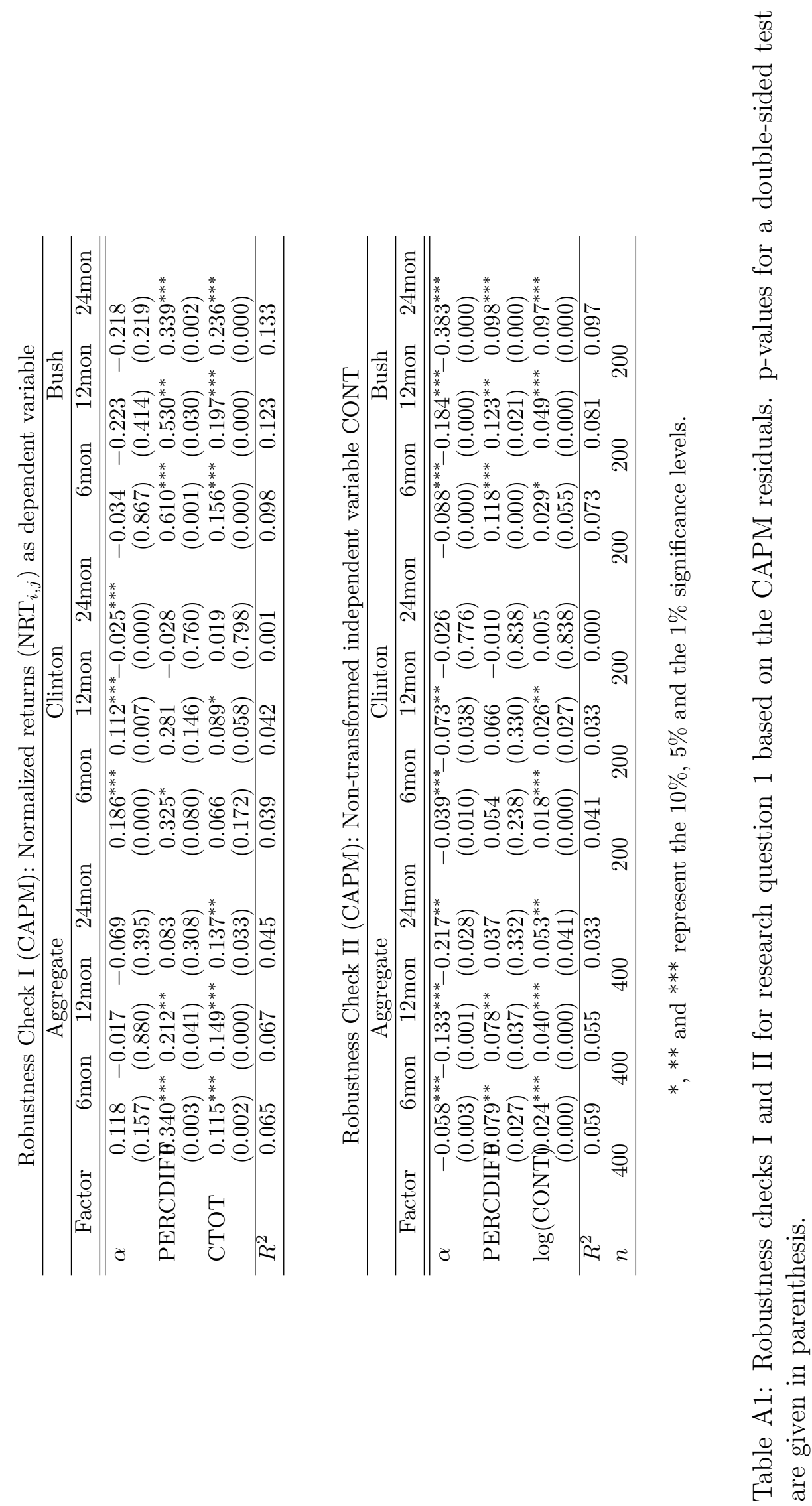

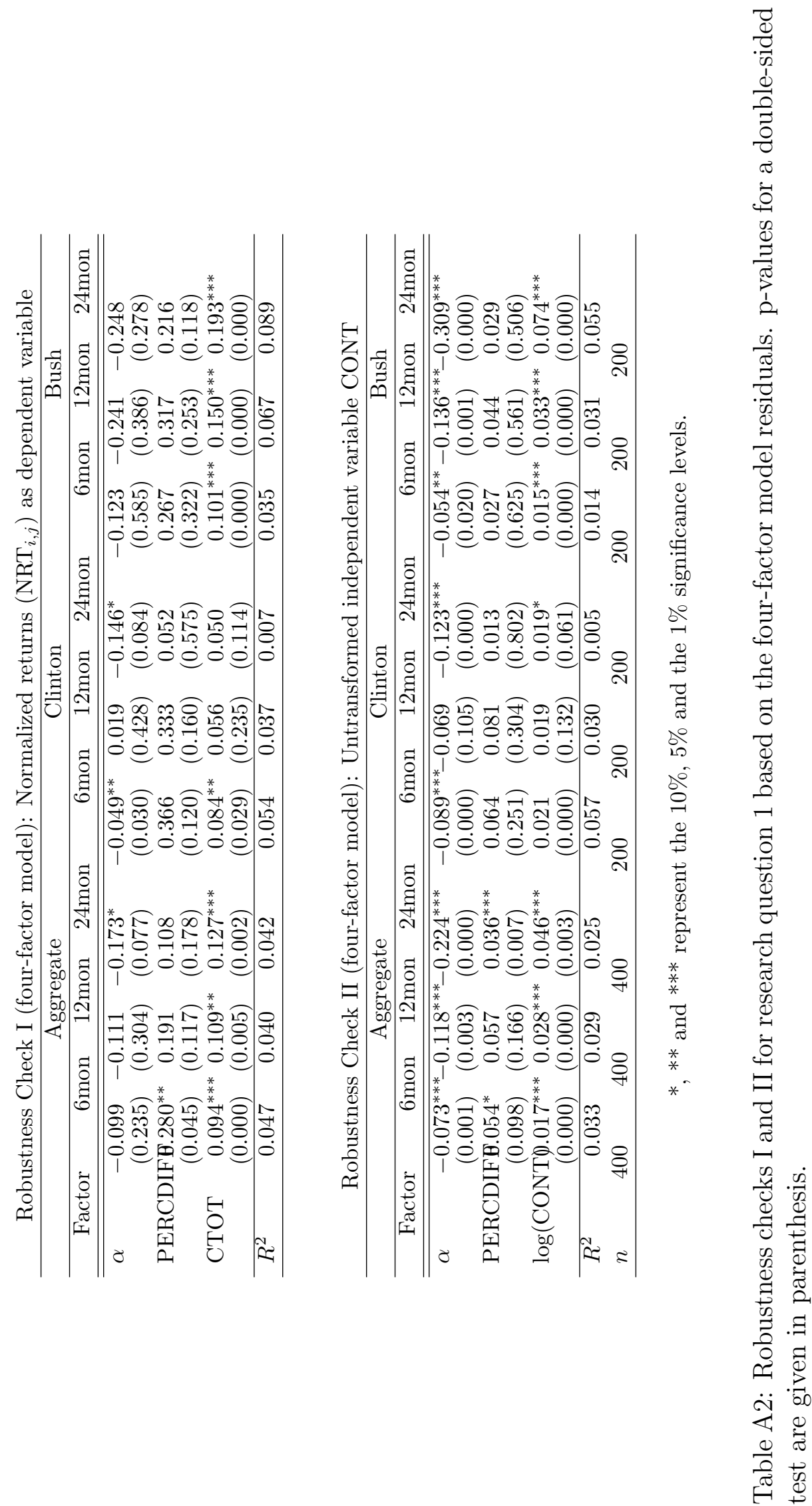

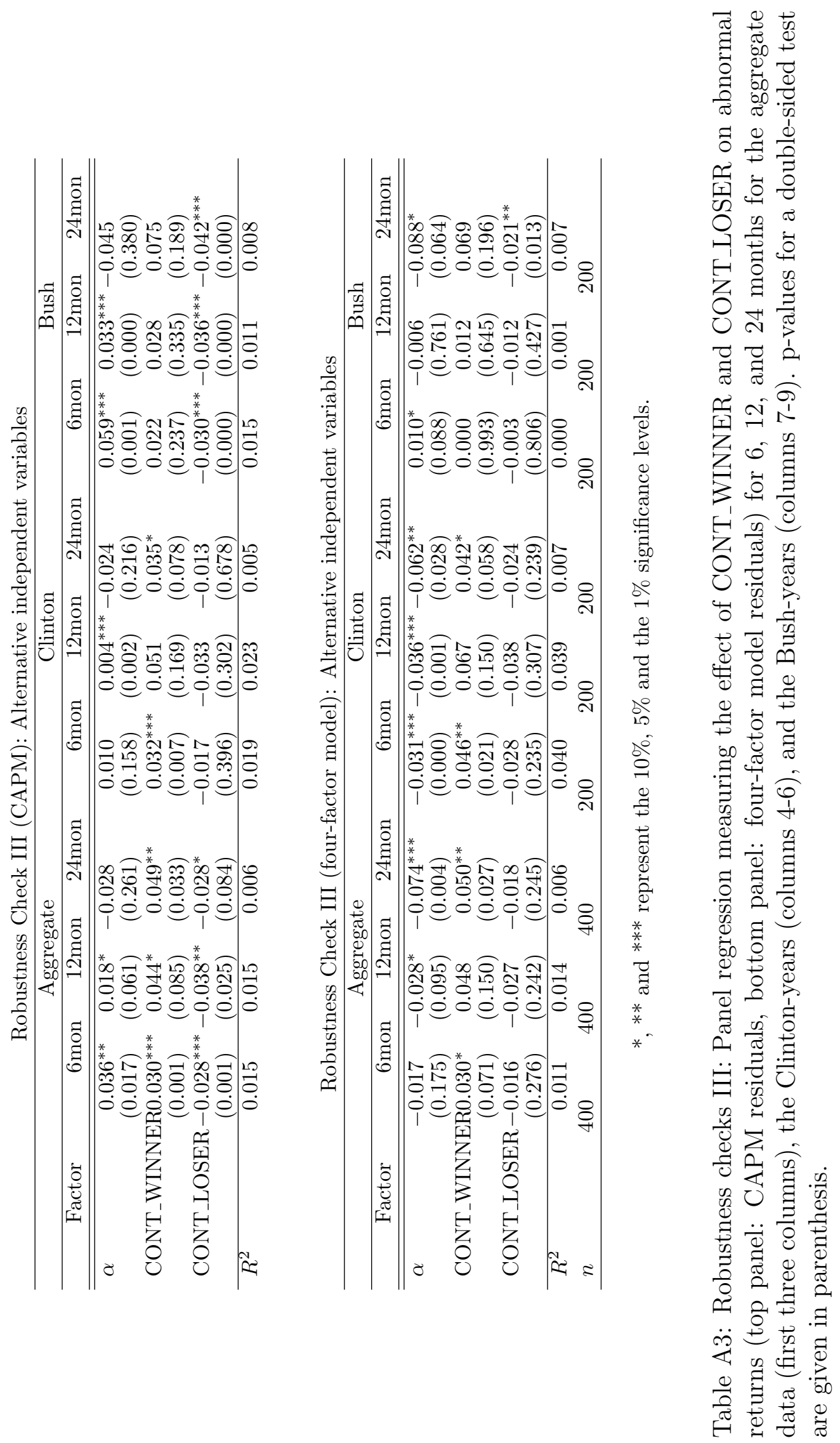


\section{University of Innsbruck - Working Papers in Economics and Statistics Recent papers}

2008-18 Jürgen Huber and Michael Kirchler: Corporate Campaign Contributions as a Predictor for Abnormal Stock Returns after Presidential Elections.

2008-17 Wolfgang Brunauer, Stefan Lang, Peter Wechselberger and Sven Bienert: Additive Hedonic Regression Models with Spatial Scaling Factors: An Application for Rents in Vienna.

2008-16 Harald Oberhofer, Tassilo Philippovich: Distance Matters! Evidence from Professional Team Sports.

2008-15 Maria Fernanda Rivas and Matthias Sutter: Wage dispersion and workers' effort.

2008-14 Stefan Borsky and Paul A. Raschky: Estimating the Option Value of Exercising Risk-taking Behavior with the Hedonic Market Approach.

2008-13 Sergio Currarini and Francesco Feri: Information Sharing Networks in Oligopoly.

2008-12 Andrea M. Leiter: Age effects in monetary valuation of mortality risks - The relevance of individual risk exposure.

2008-11 Andrea M. Leiter and Gerald J. Pruckner: Dying in an Avalanche: Current Risks and their Valuation.

2008-10 Harald Oberhofer and Michael Pfaffermayr: Firm Growth in Multinational Corporate Groups.

2008-09 Michael Pfaffermayr, Matthias Stöckl and Hannes Winner: Capital Structure, Corporate Taxation and Firm Age.

2008-08 Jesus Crespo Cuaresma and Andreas Breitenfellner: Crude Oil Prices and the Euro-Dollar Exchange Rate: A Forecasting Exercise.

2008-07 Matthias Sutter, Stefan Haigner and Martin Kocher: Choosing the carrot or the stick? - Endogenous institutional choice in social dilemma situations.

2008-06 Paul A. Raschky and Manijeh Schwindt: Aid, Catastrophes and the Samaritan's Dilemma.

2008-05 Marcela Ibanez, Simon Czermak and Matthias Sutter: Searching for a better deal - On the influence of group decision making, time pressure and gender in a search experiment.

2008-04 Martin G. Kocher, Ganna Pogrebna and Matthias Sutter: The Determinants of Managerial Decisions Under Risk.

2008-03 Jesus Crespo Cuaresma and Tomas Slacik: On the determinants of currency crises: The role of model uncertainty.

2008-02 Francesco Feri: Information, Social Mobility and the Demand for Redistribution.

2008-01 Gerlinde Fellner and Matthias Sutter: Causes, consequences, and cures of myopic loss aversion - An experimental investigation. Revised version forthcoming in Economic Journal.

2007-31 Andreas Exenberger and Simon Hartmann: The Dark Side of Globalization. The Vicious Cycle of Exploitation from World Market Integration: Lesson from the Congo.

2007-30 Andrea M. Leiter and Gerald J. Pruckner: Proportionality of willingness to pay to small changes in risk - The impact of attitudinal factors in scope tests. Revised version forthcoming in Environmental and Resource Economics.

2007-29 Paul Raschky and Hannelore Weck-Hannemann: Who is going to save us now? Bureaucrats, Politicians and Risky Tasks.

2007-28 Harald Oberhofer and Michael Pfaffermayr: FDI versus Exports. Substitutes or Complements? A Three Nation Model and Empirical Evidence.

2007-27 Peter Wechselberger, Stefan Lang and Winfried J. Steiner: Additive models with random scaling factors: applications to modeling price response functions. 
2007-26 Matthias Sutter: Deception through telling the truth?! Experimental evidence from individuals and teams. Revised version accepted for publication in The Economic Journal.

2007-25 Andrea M. Leiter, Harald Oberhofer and Paul A. Raschky: Productive disasters? Evidence from European firm level data.

2007-24 Jesus Crespo Cuaresma: Forecasting euro exchange rates: How much does model averaging help?

2007-23 Matthias Sutter, Martin Kocher and Sabine Strauß: Individuals and teams in UMTS-license auctions. Revised version with new title "Individuals and teams in auctions" forthcoming in Oxford Economic Papers.

2007-22 Jesus Crespo Cuaresma, Adusei Jumah and Sohbet Karbuz: Modelling and Forecasting Oil Prices: The Role of Asymmetric Cycles.

2007-21 Uwe Dulleck and Rudolf Kerschbamer: Experts vs. discounters: Consumer free riding and experts withholding advice in markets for credence goods. Revised version forthcoming in "International Journal of Industrial Organization".

2007-20 Christiane Schwieren and Matthias Sutter: Trust in cooperation or ability? An experimental study on gender differences. Revised version published in Economics Letters 99 (2008): 494-497.

2007-19 Matthias Sutter and Christina Strassmair: Communication, cooperation and collusion in team tournaments - An experimental study. Revised version forthcoming in: Games and Economic Behavior.

2007-18 Michael Hanke, Jürgen Huber, Michael Kirchler and Matthias Sutter: The economic consequences of a Tobin-tax - An experimental analysis.

2007-17 Michael Pfaffermayr: Conditional beta- and sigma-convergence in space: A maximum likelihood approach. Revised version forthcoming in Regional Science and Urban Economics.

2007-16 Anita Gantner: Bargaining, search, and outside options. Published in: Games and Economic Behavior, Vol. 62 (2008), pp. 417-435.

2007-15 Sergio Currarini and Francesco Feri: Bilateral information sharing in oligopoly.

2007-14 Francesco Feri: Network formation with endogenous decay.

2007-13 James B. Davies, Martin Kocher and Matthias Sutter: Economics research in Canada: A long-run assessment of journal publications. Revised version published in: Canadian Journal of Economics, Vol. 41 (2008), 22-45.

2007-12 Wolfgang Luhan, Martin Kocher and Matthias Sutter: Group polarization in the team dictator game reconsidered. Revised version forthcoming in: Experimental Economics.

2007-11 Onno Hoffmeister and Reimund Schwarze: The winding road to industrial safety. Evidence on the effects of environmental liability on accident prevention in Germany.

2007-10 Jesus Crespo Cuaresma and Tomas Slacik: An "almost-too-late" warning mechanism for currency crises.

2007-09 Jesus Crespo Cuaresma, Neil Foster and Johann Scharler: Barriers to technology adoption, international R\&D spillovers and growth.

2007-08 Andreas Brezger and Stefan Lang: Simultaneous probability statements for Bayesian P-splines.

2007-07 Georg Meran and Reimund Schwarze: Can minimum prices assure the quality of professional services?.

2007-06 Michal Brzoza-Brzezina and Jesus Crespo Cuaresma: Mr. Wicksell and the global economy: What drives real interest rates?.

2007-05 Paul Raschky: Estimating the effects of risk transfer mechanisms against floods in Europe and U.S.A.: A dynamic panel approach.

2007-04 Paul Raschky and Hannelore Weck-Hannemann: Charity hazard - A real hazard to natural disaster insurance. Revised version forthcoming in: Environmental Hazards. 
2007-03 Paul Raschky: The overprotective parent - Bureaucratic agencies and natural hazard management.

2007-02 Martin Kocher, Todd Cherry, Stephan Kroll, Robert J. Netzer and Matthias Sutter: Conditional cooperation on three continents. Revised version forthcoming in: Economics Letters.

2007-01 Martin Kocher, Matthias Sutter and Florian Wakolbinger: The impact of naïve advice and observational learning in beauty-contest games. 


\title{
University of Innsbruck
}

\section{Working Papers in Economics and Statistics}

\section{$2008-18$}

Jürgen Huber, Michael Kirchler

Corporate campaign contributions and abnormal stock returns after presidential elections

\begin{abstract}
Contributions by investor-owned companies play major roles in financing the campaigns of candidates for elective office in the United States. We look at the presidential level and analyze contributions by companies before an election and their stock market performance following US presidential elections from 1992 to 2004. We find that companies experienced abnormal positive post-election returns with (i) a higher percentage of contributions given to the eventual winner and (ii) with a higher total contribution given. Hypothetical portfolios of the 30 largest corporate contributors formed according to (i) the percentage of contributions given to the winner in a presidential election and (ii) the total contribution (divided by market capitalization) would have earned significant abnormal returns in the two years after an election. While all results hold for Bill Clinton and George W. Bush, they are stronger by a magnitude of two to three under W. Bush.
\end{abstract}

ISSN 1993-4378 (Print)

ISSN 1993-6885 (Online) 